\title{
Service Quality Dimensions: Key on Customer Satisfaction a Glance on Commercial Bank of Ethiopia
}

\author{
Sintayehu Assefa (PhD Candidate) \\ School of Graduate Studies, Department of Management, University of Arba Minch - Ethiopia
}

\begin{abstract}
This descriptive study strives to examine the effect of service quality on customer satisfaction in Banking Industries. In today's competitive business, delivering quality service is the key and undeniable for a sustainable growth, competitive advantage and even survival for any of organizations to stay in this dynamic and turbulent environment. Satisfied customers are the bases for any successful business as customer satisfaction leads to repeated purchase, brand loyalty, and positive word of mouth which will have a positive impact on the success of the organization. The aim of the study was to apply SERVQUAL model in the context of service quality of Commercial Bank of Ethiopia, Leku Branch. The study showed that five service quality dimensions have a positive and significant relationship with customer satisfaction. The researcher has used descriptive research method and both primary and secondary data were used. To collect primary data, questionnaires were distributed for the customers of the Bank, Leku, Branch. The study also indicated that the collected data have been analyzed using descriptive and inferential statistics. The finding advised that the Bank (Leku Branch) needs to improve all dimensions of service quality.
\end{abstract}

Keywords: SERVQUAL, Bank, Tangibility, Reliability, Assurance, Responsiveness, Empathy and Customer Satisfaction.

DOI: $10.7176 /$ IEL/9-3-02

Publication date: April $30^{\text {th }} 2019$

\section{INTRODUCTION}

Globalization and open market system have created the complex competitive environment not only for the manufacturing sector but also for service sector. The principal objectives of organizations is to maximize profit and to minimize cost profit maximization can through increase sales with lesser costs. One of the factor that can help to increase sales is customer satisfaction, because satisfaction leads to customer loyalty, recommendation and repeat purchase. Customer satisfaction has been a subject of great interest to organizations and researchers alike (Bennett. and Barkensio, 2005). Customers become very vital in business during the marketing era of the 1950, when companies could produce what they can sale and not just selling what they can produce as it was during production era. Since the beginning of the competition era in marketing, the focus of customers/consumers has increased more as the competition era also shift to post-competition; where organizations are obliged to reader more service in addition to what they provide as offers to their customers (Baumann, 2007).

Customer satisfaction has been a subject of great interest to organizations and researchers alike. The principal objective of organizations is to maximize profits and to minimize cost. Profit maximization can be achieved through increase in sales with lesser costs. One of the factors that can help to increase sales is customer satisfaction, because satisfaction leads to customer loyalty recommendation and repeat purchase (Wilson et al., 2008).

Although there are other factors such as price, product quality e.t.c other than service quality that determine customer satisfaction (Wilson et al.; 2008, Ladhari, 2009). Customers are clearly more pleased with superior quality service and when a company gains the customers satisfaction, profitability is ensured hence, assessing their relationship can be beneficial for the management in the companies. Since customer's satisfaction has been considered to be based on the customer's experience on a particular service encounter, it is in line with the fact that service quality is a determinant of customer satisfaction, because service quality comes from outcome of the service from service providers in organizations (Zeithaml, 2009).

Highly satisfied customers produce several benefit for the organization, they talk favorably to others bout the organization and its product and remain loyal for long period, the opposite is true in the case of dissatisfied customers, they "disparage" the product or service to others and give high attention for competitors as a result the organization incur loss (Kottler and Keller, 2014, Jain and Gupta, 2004). Customer satisfaction has a positive impact on firm profitability. "The cumulative customer satisfaction is seen to be based on the total purchase and consumption experience with a good or service over time and as such, is a more fundamental indicator of the firms past, current and future performance''(Arasli et al., 2005;). The study will focus on assessing the effect of service quality on customers' satisfaction, the case of Commercial Bank of Ethiopia, Leku branch.

Today, many Banking industries are going to expand their branch in to different region and sub-region of the country. Leku is a town found in Shebedeno Woreda in Sidama Zone and one of the growing towns in 
Sidama Zone. The research mainly focus on the assessment of service quality on customer satisfaction in Banking industries, a case of Commercial Bank of Ethiopia in Leku branch which is the oldest branch operating in service giving industries. The importance of customers in the business operation made it critical to conduct research about customers. There has been the need for customer research before, during and after sales, because of change that may occur in the operation of business.

As stated by Razak (2008) "an organization that consistently satisfies its customers, enjoy higher retention levels and greater profitability due to increase customer loyalty". For this reason every company works hard daily to win the hearts of customers by satisfying them in order that they become loyal customers to their brands in order to increase sales and profit. When customers have good perceptions about a brand, they will always choose to go for the brand, because consumers form their preferences relative to perceptions and attitudes about the brands competing in their minds.

\subsection{Statement of the problem}

Customer satisfaction has been studied in different directions, from measurement to its relationships with other business aspects. Some researchers have provided possible means of measuring customer satisfaction (Lovelock and Wirtz, 2007). Meanwhile other authors like Wilson et al., (2008) demonstrated some determinants of customer satisfaction to be product and service quality, price, personal and situational factors (Wilson et al., 2008). Some researchers have looked into the relationship between total quality management and customer satisfaction (Stephen and Bart, 2012). Because customer satisfaction is also based upon the level of service quality provided by the service provider (Kumra, 2008) and service quality acts as a determinant of customer satisfaction which also supported by the study made by (Wilson et al., 2008). Other authors have brought out theories relating customer satisfaction and service quality in their researches.

In another interrelated study made by Wangenheim (2003) measured service quality in China's mobile phone market and emphasis on the dynamic relationship among service quality, customer value, customer satisfaction and their influence on future behaviors after the key drives of customer value and customer satisfaction are identified.

In relating customer satisfaction and service quality, researchers have been more precise about the meaning and measurements of satisfaction and service quality. Although it is stated that other factors such as price and product quality can affect customer satisfaction, perceived service quality is a component of customer satisfaction (Jannatul, 2010). Service quality is a focused evaluation reflecting the customer's perception of specific service dimensions including reliability, responsiveness, assurance, empathy, and tangibility (Zeithaml, 2009).

Ethiopia's Banking industry is relatively undeveloped which is exemplified by the sectors low penetration levels. There are an estimated 50 Million formal bank clients in Ethiopia as per the data obtained from National Bank of Ethiopia (NBE). Ethiopian Banking industry service shown less performance to serve customers need. Most Banking industries are facing challenges of delivering quality service towards creating satisfied customers and here the gap between service quality and expectation may result in abnormal relationship with customer satisfaction.

Today, Ethiopian Banking industries are going to stiff completion. So, it becomes very vital to meet or exceed the target customers' satisfaction with delivering quality service. The study centered on Leku Branch to infer whether it provide quality service to create delight customers or not. Keeping in mind the above gaps, the research answered the following questions

- What is the relationship between reliability and customer satisfaction?

- What is the relationship between assurance and customer satisfaction?

- What is the relationship between tangibility and customer satisfaction?

- What is the relationship between empathy and customer satisfaction?

- What is the relationship between responsiveness and customer satisfaction?

\subsection{Objective of the study}

The general objective of the study is to assess service quality on customer satisfaction, the case of Commercial Bank of Ethiopia, Leku branch.

The specific objectives are:

- To determine relevant importance of reliability for customer satisfaction.

- To determine relevant importance of assurance for customer satisfaction.

- To determine relevant importance of empathy for customer satisfaction.

- To examine the relationship between responsiveness and customer satisfaction.

- $\quad$ To examine the relationship between tangibility and customer satisfaction. 


\section{Review of Related Literature}

This portion of the study aim to show literature important to the study and to provide a theoretical frame work. This chapter also consists of definition, concepts, theoretical literature, empirical evidence and conceptual frame work of the study.

\subsection{Definition of Service}

Kotler defines service as "any intangible act or performance that one party offers to another that does not result in the ownership of anything" (Kotler and Keller, 2014). Services are the production of an essential benefit, either in its own right or as a significant, not incidental, element of a tangible product, which through some form of exchange satisfies an identifiable customer need (Miller and Layton, 2009; Santouridis and Trivellas, 2010).

\subsection{Service Quality}

In order for a company's offer to reach the customers there is a need for services. These services depend on the type of product and it differs in the various organizations. Service can be defined in many ways depending on which area the term is being used. An author defines service as "any intangible act or performance that one party offers to another that does not result in the ownership of anything" (Kotler and Keller, 2014). In all, service can also be defined as an intangible offer by one party to another in exchange of money for pleasure.

Quality is one of the things that consumers look for in an offer, which service happens to be one (Elizabeth, 2006). Quality can also be defined as the totality of features and characteristics of a product or services that bear on its ability to satisfy stated or implied needs. It is evident that quality is also related to the value of an offer, which could evoke satisfaction or dissatisfaction on the part of the user.

One of the most useful measurements of service quality is the dimensions from the SERVQUAL model. In the creation of this model for the very first time, Parasuraman et al., (1985) identified 97 attributes which were condensed into ten dimensions; they were found to have an impact on service quality and were regarded as the criteria that were important to access customer's expectations and perceptions on delivered service (Kumar, 2009).

The SERVQUAL scale which is also known as the gap model by Parasuraman et al., (1988) has been proven to be one of the best ways to measure the quality of services provided to customers. This service evaluation method has been proven consistent and reliable by some authors (Bowen and David, 2005). They held that, when perceived or experienced service is less than the expected service; it implies less than satisfactory service quality; and when perceived service is more than expected service, the obvious inference is that service quality is more than satisfactory (Kuar, 2012). From the way this theory is presented, it seems the idea of SERVQUAL best fits the evaluation of service quality form the customer perspective. This is because when it is stated "perceived" and "expected" service, it is very clear that this goes to the person, who is going to or is consuming the service; who definitely is the consumer/customer.

\subsection{Dimensions of service quality}

The SERVQUAL Instrument measures the five dimensions of Service Quality. These five dimensions are: tangibility, reliability, responsiveness, assurance and empathy. In first SERVQUAL model that came had 22 pairs of Likert-type items, where one part measured perceived level of service provided by a particular organization and the other part measured expected level of service quality by respondent (Lee and Hwan, 2005). Further investigation led to the finding that, among these 10 dimensions, some were correlated. After refinement, these ten dimensions above were later reduced to five dimensions as below.

With regard to reliability as Eshghi(2008) disclosed that it is the ability to perform the promised service dependably and accurately. Reliability means that the company delivers on its promises-promises about delivery, service provision, problem resolutions and pricing. Customers want to do business with companies that keep their promises, particularly their promises about the service outcomes and core service attributes. All companies need to be aware of customer expectation of reliability. Firms that do not provide the core service that customers think they are buying fail their customers in the most direct way (Negi, 2009).

Considering the dimension of Assurance, it means to inspire trust and confidence. Assurance is defined as employees' knowledge of courtesy and the ability of the firm and its employees to inspire trust and confidence (Yee and Cheng, 2010). This dimension is likely to be particularly important for the services that the customers perceives as involving high rising and/or about which they feel uncertain about the ability to evaluate. Trust and confidence may be embodied in the person who links the customer to the company, for example, the marketing department. Thus, employees are aware of the importance to create trust and confidence from the customers to gain competitive advantage and for customers' loyalty (Ghylin et al., 2006).

The third dimension is responsiveness defined by Gronroos (2007) which is the willingness to help customers and provide prompt service. This dimension emphasizes attentiveness and promptness in dealing with customer's requests, questions, complaints and problems. Responsiveness is communicated to customers by 
length of time they have to wait for assistance, answers to questions or attention to problems. Responsiveness also captures the notion of flexibility and ability to customize the service to customer needs (Al-Hawary, 2011).

The fourth is related with empathy which means to provide caring individualized attention the firm provide its customers. In some countries, it is essential to provide individual attention to show to the customer that the company does best to satisfy his needs. Empathy is an additional plus that the trust and confidence of the customers and at the same time increase the loyalty. In this competitive world, the customer's requirements are rising day after day and it is the companies' duties to their maximum to meet the demands of customers, else customers who do not receive individual attention will search elsewhere (Gilbert et al. 2005).

The last one is tangibility which outlines that services are tangible, customers derive their perception of service quality by comparing the tangible associated with these services provided. It is the appearance of the physical facilities, equipment, personnel and communication materials. In this survey, on the questionnaire designed, the customers respond to the questions about the physical layout and the facilities offers to its customers. The aggregated sum of difference between perceptions and expectations from the five dimensions forms the global perceive quality construct.

\section{RESEARCH METHODOLOGY}

The aim of this section is to explain methods used in carrying out this research, how the research will be designed, sampling technique and reasons for the choices. The chapter presents data collection and data analysis methods employed in the research.

\subsection{Research Design}

The research used a descriptive study. A descriptive study aimed to create an accurate profile of persons, events or situations (Robson, 2002). Another author adds that a descriptive study may means to establish only associations between variables (Hopkins, 2009). The reason for this choice centered on the research objective "to examine the relationship between customer satisfaction and service quality with respect to the service quality dimensions" and on the way in which the research questions will be structured. Also the research used descriptive design since a descriptive study establishes only association between variables on what the researcher will try to do; creating an accurate profile of a situation about the relationship between customer satisfaction and service quality. Another reason that causes the researcher to design this research as a descriptive study is because the researcher will not make any attempt to change the behavior of the variables measured (Hopkins, 2001).

Moreover, the research followed a cross-sectional study because the research used more than one case in the research and in cross-sectional studies variables of interest in a sample of subjects are tested once and the relationships between them are determined (Hopkins, 2001).

\subsection{POPULATION AND SAMPLING PROCEDURES}

\subsubsection{Study population}

The target population of this study would be customers those who receive service from the Commercial Bank of Ethiopia residing in Leku Branch.

\subsubsection{Sampling Design}

The researcher used non-probability sampling specifically convenience sampling to select customers to represent all population of the study. The reason behind this technique is it is easy to analyze and give equal chance for the respondent. This study selects some representative (samples) from the total population to draw valuable conclusion about customers. So to keep accuracy of data 384 respondents customers were selected from all categories of customers residing in Leku town.

\subsection{Data collection procedures}

The study employed both primary and secondary sources for collecting facts and figures relating to the topic under research. The primary data was collected with the help of questionnaire. Secondary source includes previous reports, procurement trackers, quarter and year end reports and various websites, which provide information for building up the theoretical and conceptual framework of the study.

This study used a structured type of questionnaire as its main technique of data collection. The choice of the instrument was based on the fact that the study were quantitative in nature. Prior to distribution of the questionnaire, the questionnaire was pre-tested by conducting the pilot survey on customers of Commercial Bank of Ethiopia residing in Leku town to verify that important factors were not omitted. Based on the response of the respondents the questions were revised. Then, the revised questionnaire was distributed to a sample of active customers in order to measure and assess to what extent their service delivery on customer satisfaction. Questionnaires was employed as a source of data collection for a number of reasons. First of all, a large number of questions incorporated. In addition, questionnaire used to cover a large number of respondents. In addition, using the questionnaire the researcher can measure the effectiveness of the service quality dimension on 
customer satisfaction. The questionnaires was developed in search of the study objectives with close-ended questions, designed from literature review.

\section{Descriptive statistics Analysis}

Table 4.1. Average mean for independent and dependent variables

\begin{tabular}{|l|l|r|r|}
\hline & N & \multicolumn{1}{|l|}{ Mean } & Std. Deviation \\
\hline Reliability & 384 & 3.69 & 1.099 \\
\hline Responsiveness & 384 & 4.01 & 0.71 \\
\hline Assurance & 384 & 3.86 & 0.881 \\
\hline Empathy & 384 & 3.8 & 1.014 \\
\hline Tangibles & 384 & 3.53 & 1.023 \\
\hline Customer satisfaction & 384 & 4.02 & 0.929 \\
\hline Valid N (listwise) & 384 & & \\
\hline
\end{tabular}

\section{Source: Survey 2018/2019}

Table 4.1. depicted that, mean values and the values of the standard deviation of the independent variable (five dimensions of service quality) have been depicted. Mean value provides the idea about central tendency of the values of a variable summarizes the level of satisfaction of the respondents towards five dimensions of service quality. Standard deviation measures the dispersion of a given data set. In view of the above Table 4.1, reliability has the average mean score of 3.69 with the standard deviation of 1.099 , responsiveness has the mean value of 4.01 with the standard deviation of 0.71 , assurance has resulted the mean of 3.86 with the standard deviation of 0.881 , empathy has resulted in the mean score of 3.80 with the standard deviation of 1.014 , tangibles has the mean value of 3.53 with the standard deviation of 1.023 and the average mean score of dependent variable (customer satisfaction) 4.02 with the standard deviation of 0.929 . In conclusion, customers were satisfied with service quality dimension of responsiveness as compared with the rest. The above table also depicted that the mean score of general customer satisfaction is 4.07 with the standard deviation of 0.919 . To sum up, customers were satisfied with the service quality dimensions of the bank.

\subsection{Inferential analysis of the study}

\subsubsection{Pearson correlation analysis}

Karl Pearson's coefficient of correlation is also known as the product moment correlation coefficient. The value of ' $r$ ' lies between \pm 1 . Positive values of $r$ indicate positive correlation between the two variables (i.e., changes in both variables take place in the statement direction), whereas negative values of ' $r$ ' indicate negative correlation i.e., changes in the two variables taking place in the opposite directions. A zero value of ' $r$ ' indicates that there is no association between the two variables. When $r=(+) 1$, it indicates perfect positive correlation and when it is $(-) 1$, it indicates perfect negative correlation, meaning thereby that variations in independent variable (X) explain $100 \%$ of the variations in the dependent variable (Y). We can also say that for a unit change in independent variable, if there happens to be a constant change in the dependent variable in the same direction, then correlation will be termed as perfect positive. But if such change occurs in the opposite direction, the correlation will be termed as perfect negative. The value of ' $r$ ' nearer to +1 or -1 indicates high degree of correlation between the two variables. 
Table 4.2. Pearson correlation analysis

\begin{tabular}{|c|c|c|c|c|c|c|c|}
\hline \multicolumn{2}{|l|}{ Variables } & Reliability & Responsiveness & Assurance & Empathy & Tangibles & $\begin{array}{l}\text { Customer } \\
\text { satisfaction }\end{array}$ \\
\hline \multirow[t]{3}{*}{ Reliability } & $\begin{array}{l}\text { Pearson } \\
\text { Correlation }\end{array}$ & 1 & $.404 * *$ & $.571 * *$ & $.436^{* *}$ & $.249 * *$ & $.833 * *$ \\
\hline & $\begin{array}{ll}\text { Sig. } & (2- \\
\text { tailed })\end{array}$ & & 0 & 0 & 0 & 0.001 & 0 \\
\hline & $\mathrm{N}$ & 384 & 384 & 384 & 384 & 384 & 384 \\
\hline \multirow[t]{3}{*}{ Responsiveness } & $\begin{array}{l}\text { Pearson } \\
\text { Correlation }\end{array}$ & $.404 * *$ & 1 & $.499 * *$ & $.581 * *$ & $.407 * *$ & $.429 * *$ \\
\hline & $\begin{array}{ll}\text { Sig. } & (2- \\
\text { tailed })\end{array}$ & 0 & & 0 & 0 & 0 & 0 \\
\hline & $\mathrm{N}$ & 384 & 384 & 384 & 384 & 384 & 384 \\
\hline \multirow[t]{3}{*}{ Assurance } & $\begin{array}{l}\text { Pearson } \\
\text { Correlation }\end{array}$ & $.571 * *$ & $.499 * *$ & 1 & $.502 * *$ & $.588 * *$ & $.668 * *$ \\
\hline & $\begin{array}{ll}\text { Sig. } & (2- \\
\text { tailed) }\end{array}$ & 0 & 0 & & 0 & 0 & 0 \\
\hline & $\mathrm{N}$ & 384 & 384 & 384 & 384 & 384 & 384 \\
\hline \multirow[t]{3}{*}{ Empathy } & $\begin{array}{l}\text { Pearson } \\
\text { Correlation }\end{array}$ & $.436 * *$ & $.581 * *$ & $.502 * *$ & 1 & $.279 * *$ & $.464 * *$ \\
\hline & $\begin{array}{ll}\text { Sig. } & (2- \\
\text { tailed }) & \\
\end{array}$ & 0 & 0 & 0 & & 0 & 0 \\
\hline & $\mathrm{N}$ & 384 & 384 & 384 & 384 & 384 & 384 \\
\hline \multirow[t]{3}{*}{ Tangibles } & $\begin{array}{l}\text { Pearson } \\
\text { Correlation }\end{array}$ & $.249 * *$ & $.407 * *$ & $.588 * *$ & $.279 * *$ & 1 & $.409 * *$ \\
\hline & $\begin{array}{l}\text { Sig. } \\
\text { tailed) }\end{array}$ & 0.001 & 0 & 0 & 0 & & 0 \\
\hline & $\mathrm{N}$ & 384 & 384 & 384 & 384 & 384 & 384 \\
\hline \multirow[t]{3}{*}{$\begin{array}{l}\text { Customer } \\
\text { satisfaction }\end{array}$} & $\begin{array}{l}\text { Pearson } \\
\text { Correlation }\end{array}$ & $.833 * *$ & $.429 * *$ & $.668 * *$ & $.464 * *$ & $.409 * *$ & 1 \\
\hline & $\begin{array}{ll}\text { Sig. } \\
\text { tailed })\end{array}$ & 0 & 0 & 0 & 0 & 0 & \\
\hline & $\mathrm{N}$ & 384 & 384 & 384 & 384 & 384 & 384 \\
\hline
\end{tabular}

\section{Source: Survey 2018/2019}

**. Correlation is significant at the 0.01 level (2-tailed).

The results in Table 4.2. indicate that, there is positive and significant relationship between all service quality dimensions and again all service quality dimensions have positive and significant relationship with dependent variable (customer satisfaction). In addition, Table 4.2 indicated that there is positive and significant relationship between reliability and customer satisfaction $(r=833, p<0.01)$, responsiveness and customer satisfaction $(\mathrm{r}=.429, \mathrm{p}<0.01)$, assurance and customer satisfaction $(\mathrm{r}=.668, \mathrm{p}<0.01)$, empathy and customer satisfaction $(r=.464, p<0.01)$, tangibles and customer satisfaction $(r=.409, p<0.01)$. In general, from the above finding there is high positive and significant relationship between reliability and customer satisfaction followed by assurance and customer satisfaction as compared with the rest.

\subsubsection{Regression Analysis}

Table 4.3. Regression Model Summary for service quality dimensions

\begin{tabular}{|c|l|c|c|c|}
\hline Model & R & R Square & Adjusted R Square & Std. Error of the Estimate \\
\hline 1 & $.871 \mathrm{a}$ & 0.759 & 0.753 & 0.462 \\
\hline
\end{tabular}

The above Table 4.3 depicted that the $\mathrm{R}^{2}$ value of 0.759 . According to this result the independent variable (service quality dimensions) have an effect of customer satisfaction accounted 75.9 percent and the other unexplained variables which are not considered in the study accounted $24.10 \%$ have affected customer satisfaction, the adjusted $\mathrm{R}$ square is 0.753 and standard error of the estimation is 0.462 . To sum it up, in accordance with the above result customer satisfaction has highly affected by service quality other than other factors/unexplained variables. 
Table 4.4. Regression model for Coefficients.

\begin{tabular}{|c|c|c|c|c|c|c|}
\hline & & $\begin{array}{l}\text { Unstandardized } \\
\text { Coefficients }\end{array}$ & & $\begin{array}{l}\text { Standardized } \\
\text { Coefficients }\end{array}$ & & \\
\hline Model & & B & Std. Error & Beta & $\mathrm{t}$ & Sig. \\
\hline \multirow[t]{6}{*}{1} & (Constant) & 0.651 & 0.202 & & 3.221 & 0.002 \\
\hline & Reliability & 0.573 & 0.038 & 0.678 & 14.898 & 0 \\
\hline & Responsiveness & -0.025 & 0.062 & -0.019 & -0.41 & 0.682 \\
\hline & Assurance & 0.208 & 0.059 & 0.197 & 3.548 & 0 \\
\hline & Empathy & 0.044 & 0.043 & 0.048 & 1.019 & 0.31 \\
\hline & Tangibles & 0.109 & 0.042 & 0.119 & 2.605 & 0.01 \\
\hline
\end{tabular}

Source: Survey 2018/2019

a. Dependent Variable: Customer satisfaction

The results of regressions analysis, presented in Table 4.4 above, reliability has a positive and significant effect on customer satisfaction with value of beta $=0.573$, standardized coefficient beta $=0.678, \mathrm{p}<0.01$, responsiveness has negative and insignificant effect on customer satisfaction with value of beta $=-0.025$, standardized coefficient beta $=0.062, \mathrm{p}<0.01$, assurance has a positive effect on customer satisfaction with value of beta $=0.208$, standardized coefficient beta $=0.059, \mathrm{p}<0.01$, empathy has a positive and significant effect on customer satisfaction with the value of beta $=0.044$, standardized coefficient beta $=0.043, \mathrm{p}<0.01$, tangibles has a positive effect on customer satisfaction with the value of beta $=0.109$, standardized coefficient beta $=0.042$, $\mathrm{p}<0.01$. As shown in Table 4.4, responsiveness has no positive and significant effect on customer satisfaction with the beta value of (beta $=-0.031$ ). In overall, the results revealed that on one hand, the independent variable (service quality) accounted for 75.90 percent of the variance in customer satisfaction $\left(\mathrm{R}^{2}=0.759\right)$.

Thus, 75.90 percent of the variation in customer satisfaction can be affected by the five service quality dimensions and other unexplored variables may explain the variation in customer satisfaction which accounts for about 24.1 percent, shown in Table 4.10. Moreover, from the findings of this study, the researcher found out that not all of the service quality dimensions have positive impact on customer satisfaction. Out of the five service quality dimensions four dimensions (reliability, tangibles, assurance, and empathy) have positive and significant impact on customer satisfaction. On the other hand, responsiveness has a negative and insignificant influence on customer satisfaction. The findings of this study also indicated that reliability is the most important factor to have positive and significant effect on customer satisfaction.

\subsection{Findings}

The study was designed to examine the effect of service quality of the customer satisfaction in Commercial Bank of Ethiopia, Leku Branch. The primary data were collected via questionnaire from the customers of the bank and interview were conducted with the manager of the branch.

The results of descriptive statistical analysis depicted that customers were more satisfied with the reliability dimension of service quality followed by assurance and tangibles and customers were less satisfied with responsiveness and empathy of service quality dimension (Table 4.1). According to inferential analysis of the study, there is positive and significant relationship between service quality (independent variable) and customer satisfaction (dependent variable).

The correlation results of the study indicated that there is positive and significant relationship between the service quality dimensions (reliability, assurance, tangibles, responsiveness, empathy) themselves and again with the dependent variables (customer satisfaction). Strong relationship were found between reliability of service quality dimension and customer satisfaction. While, weak relationship found between empathy and customer satisfaction (Table 4.2). In general, the results revealed that all independent variables (service quality dimension) accounted for 75.9 percent of the variance in customer satisfaction $\left(\mathrm{R}^{2}=0.759\right)$. Thus, 75.9 percent of the variation in customer satisfaction can be affected by the five service quality dimensions and other unexplored variables may explain the variation in customer satisfaction which accounts for about 24.1 percent (4.11).

The regression analysis showed that reliability has a positive and significant effect on customer satisfaction. However, the finding of this study indicates that responsiveness has a negative and insignificant effect on customer satisfaction (Table 4.10).

\subsection{Recommendations}

Based on the findings of this study, the bank should work on reliability by giving training to employees to improve their sincere interest in solving customer problems, the right time and accurate service of the company since reliability highly affect customer satisfaction (Table 4.1).

The bank should also improve the assurance dimension by training its employees to make them competent enough to deliver the service and the bank should have the customer's best interest at heart and with regard to empathy dimension by providing training to employees to enhance their ability attention to give individual 
attention, to know suitable operational hour of the bank and to easily understand the customer wants and should also work on tangibility.

Generally, the bank should work on all service quality dimensions especially which affected customer satisfaction highly as stated in the finding and conclusion part of the study it accounts 75.90 percent (Table 4.3).

\section{References}

Al-Hawary, S.I.S, Alhamali, M.R. and Alghanim, A.S. (2011). Banking service quality provided by commercial banks and customer satisfaction, American Journal of Scientific Research, 27(2011).

Arasli H, Katircioglu ST, Smadi SM (2005). A comparison of service quality in the Banking industry: Some evidence from Turkish- and Greek- Speaking areas in Cyprus, Inter. J. Bank Mark.

Baumann C (2007). Predication of Attitude and Behavioral Intentions in Retail Banking, Int. J. Bank. Mark. 25(2): $102-11$.

Bennett. R and Barkensio A. (2005). Relationship quality, relationship marketing, and client perceptions of the levels of service quality of charitable organizations, International Journal of Service Industry Management.

Bowen and David E. (2005). Service Quality Blackwell encyclopaedic Dictionary of Human Resource management.

Elizabeth R. Davis (2006): The role of service quality in creating customer loyality, Doctor of Philosophy Degree, The University of Tennessee, Knoxville.

Eshghi, A. (2008). Service quality and customer satisfaction. An empirical investigation in India mobile Telecommunications services, Marketing management journal, Vol 18, number 2, p.119-144.

Eshghi, A., Roy, S. K., \& Ganguli, S. (2008). Service quality and customer satisfaction: An empirical investigation in Indian mobile Telecommunications services, Marketing Management Journal, 18(2) 119144.

Ghylin, K.M., Green, B.D., Drury, C.G., Chen, J., Schulta, J.L., Uggirala, A., Abraham, J.K. \& Lawson, T.A. (2006). Clarifying the dimensions of four concepts of quality. Theoretical issues in economics science, Vol.9,Number1,p.73-94.

Gilbert, A Churchill, Jr. and Lacobucci, D. (2005). Marketing research, Research: ethological Foundations, 9th edition. USA: Stratford publishing service.

Gronroos, C., (2007). "Service Management and Marketing: Customer Management in service Competition", 3rd Edition, John Wiley \& Sons Ltd., England, P. 483.

Jain, Sanjay K. and Gupta, Garima, (2004) measuring service quality: ServQual Vs Serperf scales the journal for decision makers; 29 (2), 25-37.

Jannatul, M. N. (2010). E-Banking and customers' satisfaction in Bangladesh: An analysis. International review of business research papers, Volume 6, no.4, September 2010.pp.145-156.

Kaur R. (2012). Impact of information technology on customer service with reference to selected banks in chandigarh. International journal of engineering and management science. vol.3 (4), 2012: 444-449.

Kotler, P. and Keller, K. L. (2014). Marketing management (13th end). New Jersey: Pearson Education Inc, Upper Saddle River.

Kumra, R., (2008). "Service Quality in Rural Tourism: A Perspective Approach". Conference on Tourism in India-Challenges Ahead, Idia, P. 424-431.

Ladhari, R. (2009). A review of twenty years of SERVQUL research,. International journal of quality and services science, Vol.1,Number 2.P.172-198.

Lee, M. C., and Hwan, I. S. (2005). Relationships among service quality, customer satisfaction and profitability in the Taiwanese banking industry. International Journal of Management, 22(4), 635-648.

Lovelock C. \& Wirtz J., (2007) "Servcies Marketing: People, Technology, Strategy, 6th Ed.,Pearson Prentice Hall, New Jersey Malik, E. M, Naeem B. and Arif, Z. (2011), How do service quality perceptions contribute in satisfying banking customers?, Interdisciplinary Journal of contemporary Research in Business, Vol. 3(8): 646- 653.

Miller and Layton (2009). Fundamentals of Marketing, Fourth Edition, Mc Graw-Hill book Company Ausralia Pvt Limit.

Negi, R. (2009). Determining customer satisfaction through perceived service quality: A study of Ethiopian mobile users, International Journal of Mobile Marketing; 4(1),31-38.

Parasuraman, A., Zeithaml, V. A., \& Berry, L. L. (1985). A conceptual model of service quality and its implications for future research, Journal of Marketing, 49, 41-50.

Parasuraman, A., Zeithaml, V. A., \& Berry, L. L. (1988). SERVQUAL: A multiple-item scale for measuring consumer perceptions of service quality, Journal of Retailing, 64 (1), p.12-40.

Razak (2008), "Service quality and student satisfaction: a case study at private higher education institutions", International Business Research, Vol. 1, No. 3 , pp. 163-75.

Santouridis, L., and Trivellas, P. (2010). Investigating the impact of service quality and customer satisfaction on 
customer loyalty in mobile telephony in Greece. TQM Journal,22(3), 330-343.

Stephen Greer and Bart Narter. (2012). Core banking solution for larger banks: a global perspective. Marsh and Mclennan companies, March 2012.

Wilson A., Zeithaml V.A., Bitner M.J., Gremler D.D. (2008) Services Marketing, McGraw-Hill Education.

Yee, R. Yeung, A., and Cheng, T. (2010). An empirical study of employee loyalty, service quality and firm performance in the service industry. International Journal of Production Economics, 124(1), 109.

Zeithaml, V. A.,( 2009): "Service Quality, Profitability, and the Economic Worth of Customers: What We Know and What We Need to Learn", Journal of Academy of Marketing Science, Volume 28(1), P.67-85. 